\title{
Research on Higher Mathematics Teaching Effective Countermeasures for Application-Oriented University under Background of Informatization
}

\author{
Wei Xiong \\ Jiangxi College of Engineering, \\ Xinyu,Jiangxi,338000 China
}

\begin{abstract}
In this paper, we conduct theoretical research on the higher mathematics teaching effective countermeasures for the application-oriented university under background of the informatization. The construction of applied undergraduate colleges and universities is an important part of Chinese higher education structure adjustment. Everything has its growth mechanism, to the understanding of the growth mechanism of the applied undergraduate colleges, and grasp is the precondition of applied undergraduate colleges and universities to build. Grow in process of building applied undergraduate colleges and universities, the main body, growing, and the basic principles of growth goal oriented. Growth is growth, growth, aim and basic principles of living water source, the growth of the accurate positioning can make growth subject according to the basic principles of achieving growth. Under this background, we propose the informatization based mathematics teaching paradigm in this paper to suggest the optimized education paradigm for our teaching system.
\end{abstract}

Keywords- Higher Mathematics, Effective Countermeasures, Application. Informatization.

\section{Introduction}

With the reform of modern higher education in China, and further, in a large number of newly built undergraduate course colleges and universities as the main body of the applied undergraduate, they have put forward slogan of cultivating applied talents, and its positioning for training characteristics. Applied undergraduate colleges and universities are to cultivate application-oriented undergraduate level that is to develop a knowledge, ability and comprehensive quality. New applied undergraduate colleges and universities generally independently upgraded or merge generated by higher vocational college education connotation in order to achieve this to seek connotation transformation is bound to experience a thought collision, the long process of the resources integration and institutional change. Higher vocational college professional and applied undergraduate professional will be in a certain period of time, no doubt this above topics for our research provides a very good case [1-3].

According to the literature review, the characteristics of the application-oriented university could be summarized as the follows. (1) Applied undergraduate teaching process combined with production practice closely, emphasizes the process of teaching orientation, emphasis on the generative and basic expansibility of the teaching process, pay more attention to curriculum design, training and practice teaching links, such as its cultivation than engineering research type talent and design talent training need more training of engineering practice, that more should have good engineering experience of the environment and atmosphere. (2) Ordinary undergraduate course emphasizes basic training goal of generality, more is to develop research and design of academic talents, and the applied undergraduate education target is applied talents, mainly including technology applied, compound applied, applied and professional application. (3) Applied undergraduate basic theory, but the most basic that also is mainly based on professional ability training, at same time, basic theories of applied 
undergraduate attention should pay close attention to practice, experiment, practice, training, testing, certification training, curriculum design, graduation design and its content should be around a line of the practical need of production design to emphasize foundation, mature and practical [4-5].

As impart profound knowledge, promote the discipline development, cultivating innovative talent of research universities, to discipline construction as leading natural; As a new applied undergraduate colleges, its development foundation, the service characteristics and factors such as training goal, the students decided to its professional talent training. Need to adhere to the employment as the guidance, according to the actual needs of society in the different development stages of talent flexible set up the professional, flexible design course according to the requirements of professional post ability of the knowledge system, the knowledge structure and the industry need docking instead of docking with the discipline as the course content need to break the subject logic relationship. For illustration, we show the keywords of the application-oriented university in figure one.

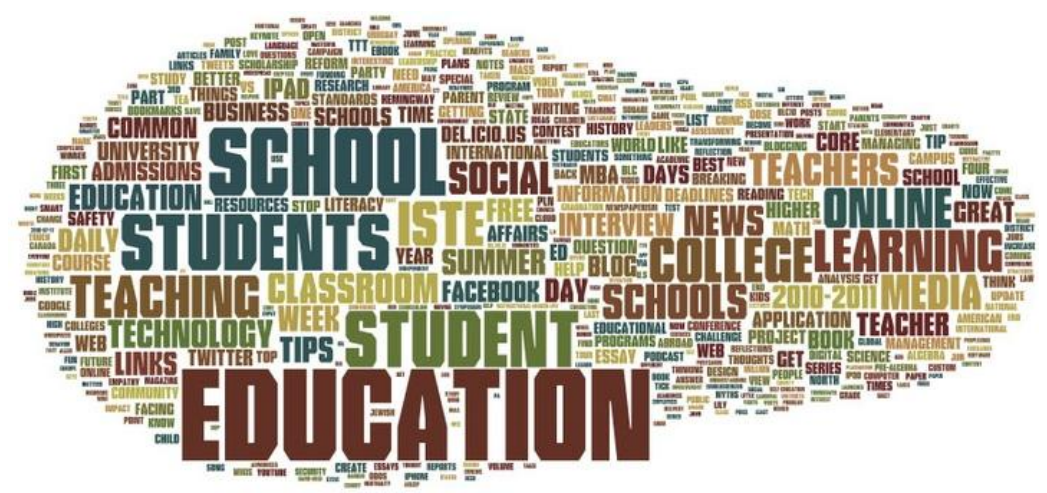

Figure 1. The Keywords of the Application-Oriented University

In this paper, we conduct research on higher mathematics teaching effective countermeasures for application-oriented university under background of the informatization. It is generally believed that applied higher education is along with the popularization of higher education from elite education to education has come into being a type of education, higher education is relative to the academic and there is a relatively independent system of higher education. In the later sections, we will combine the features of the universities to achieve more in-depth analysis on related issues.

\section{The Proposed Methodology}

The Background of the Informatization. Education informatization is the modern information technology application in the field of education. Education informatization application requirements in the process of education science and effectively on the basis of computer, multimedia and network communication of the modern information technology, reform education means and methods, so as to improve the efficiency of education. The features could be reflected from the listed aspects.

- Along with the education of information technology is widely used, the openness of the adult learning characteristics present increasingly. On the one hand, the reality of the status of the education resources distribution imbalance in the virtual world to get a certain amount of the compensation, the people can go beyond the limitations of time for autonomous learning. 
- Adult learning is permanent lifelong learning can also be understood as the adults. After the concept of the life-long education popularization, it is generally believed that the first social experience and can finish after second social learning is becoming more and more unrealistic, knowledge and information society need lifelong learning [6-7].

- In the information age, the accumulation of the knowledge and information and update speed increased dramatically, in society there emerge some new knowledge, new things, new energy and new industry, economic structure adjustment, sharply these are inseparable from the dependence on knowledge and information. At same time, information society environment factors put forward higher demands to people intelligence, to requirements of comprehensive quality of ascension intense, the human desire to update their knowledge but to swell.

The speed of knowledge updating and into realistic productivity greatly accelerated. In this case, the students learned knowledge at school after entering the society may have faced the basic fate of elimination after they left the school needs to constantly seek a variety of learning opportunities, in order to master the knowledge and skills required. Learning will become the main driving force of the social progress and the first need in one's life. School is no longer all place for student's life, students in the school is just a stage of the process of learning life, personal whole journey from birth to death must be to learn. From a technical level, education informatization is the basic characteristics of the digital, networked, intelligent and multimedia, etc. From the education level, the basic characteristics of the education informationization are the openness of the education, resource sharing, interactive learning and collaborative task. (1) The nonlinear of the teaching information organization. Human thinking and memory of knowledge is a mesh structure, through the free association choose different paths to realize the jump of basic knowledge. (2) Electronic communication and computer network information transmission is a blend of hypertext and general hypermedia technology, integrating text, graphics and images sound multimedia information transmission can eliminate the uncertainty of the information which is helpful to the understanding of the audience [8].

The Higher Mathematics Teaching. Pay attention to higher mathematics to cultivate students' logical reasoning ability and abstract thinking ability, and improve the students' mathematics quality and innovation ability. Situational teaching model is set up by teachers in the teaching process to help students to understand some situation knowledge, in turn, open learning teaching mode, pay attention to mobilize students' learning enthusiasm is a kind of education with situational teaching method.

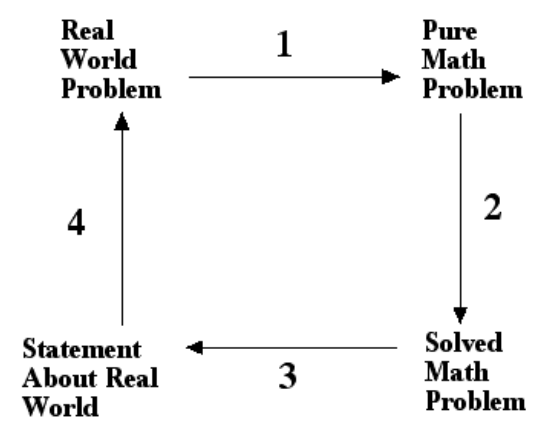

Figure 2. The Systematic Flowchart of the Higher Mathematics Teaching

Due to the higher mathematics using the highly generalization mathematical language, students tend to just understand the content of what they have learned in form, and its essential feature is not fully awareness, show the disconnection between the nature and form, the chasm between concrete and abstract, chasm between perceptual and rational. Therefore, the teaching of higher mathematics generalization of special needs from the concrete to the abstract process. 
Under this background, we propose the following teaching approaches for higher math education. (1) Heuristic teaching method. Heuristic teaching is a teaching practice an old and the new teaching method, is through the teachers guide, questions, enlightenment, and stimulate the students' learning interest and thirst for knowledge, stimulate students' positive thinking, allowing students to explore the teaching method of knowledge. (2) Case teaching method. Case teaching is in line with the aim of the organic integration of theory and practice, follow the requirements of teaching purpose, with cases as the basic material, introduces learners in a particular real situation, through the interaction between teachers and students, encourage learners to fully understand the problem of the important form of the teaching. (3) Layering method. When carrying out stratification teaching, is familiar with and master the teaching should pay enough attention to the overall goals, it is the basis of hierarchical teaching; A comprehensive understanding of the students, it is the key to the hierarchical teaching; Reasonably dividing the teaching level, reflect continuity, agility and flexibility, it is the root of the hierarchical teaching. (4) Found type teaching method. Type teaching method is in the process of the teaching, to speak content found that motivation and process as the main line, through the reasonable analysis, the closest inquiry found that the source revealed, in this way, the students will understand everything, as if the knowledge is discovered [8].

\section{The Features of Application-Oriented} University. Applied undergraduate colleges and ordinary undergraduate course teaching is the essential difference between, that more emphasis on the teaching practical application and technical. Teaching practice is the difference between applied undergraduate and the essential attribute of ordinary undergraduate teaching, in order to better cultivate talents, must highlight its practical nature, teaching of applied undergraduate colleges and universities has primary practicality. Applied undergraduate education of scientific research, emphasizes practical application value, rather than theoretical value of education, more not exploratory value of academic education.

The research mainly serves for the teaching of applied undergraduate colleges. Scientific research test is the basic theory of teaching, for teaching the use of the discipline of professional knowledge and theory, the process, not only consolidated the knowledge, and learned to the application, used in cement, and consolidated in the applied research, forming a virtuous circle and cultivate the applied talents. Applied undergraduate cultivating professional applied senior specialized talents for society line, highlight special, pertinence, practicality and professionalism, in talents cultivation, scientific research and social services differs from academic research university, and have the characteristics of distinct types of applied education and also applied undergraduate education and higher vocational education have homogeneity on the type of positioning is in training advanced applied talents in all walks of life, has the characteristics of vocational education, the undergraduate course and specialized subject education level of different applied undergraduate and higher vocational college education.

The New Paradigm for Education. Digital teaching changed the traditional teaching concept, the effective of the new era of talents. The new era of the talent training mode is the training mode of the knowledge, ability and quality in hand. In the digital teaching environment, the learners' learning is no longer dependent on the teachers' teaching and textbook knowledge, but the use of digital platform and digital resources and negotiating between teachers and students to discuss, cooperate learning. 


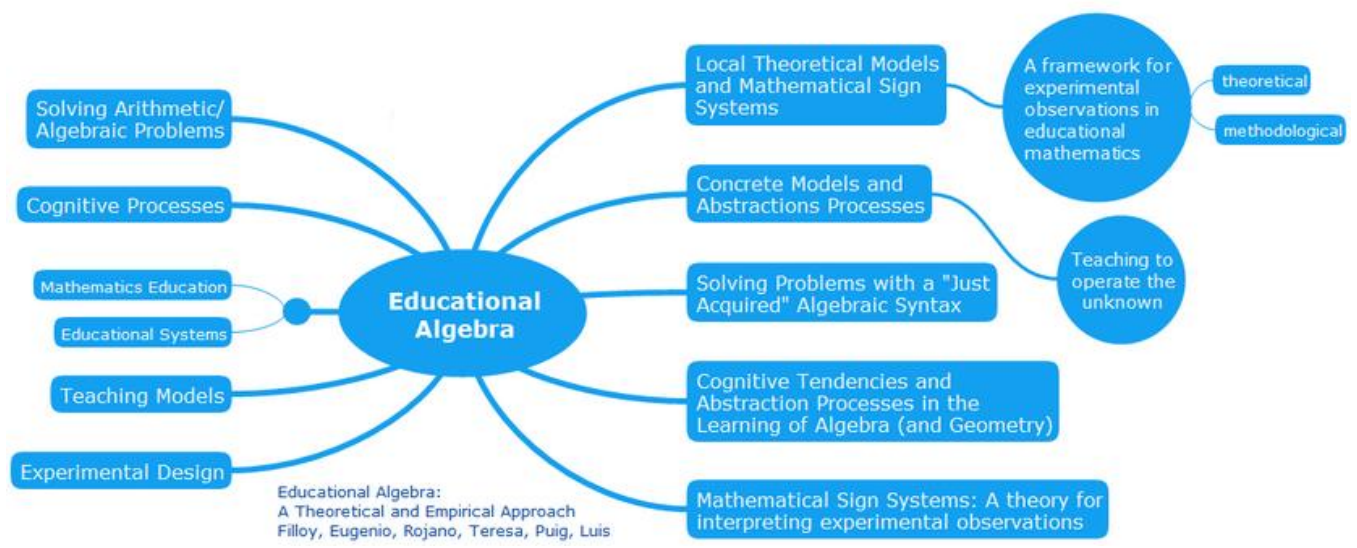

Figure 3. The Demonstrative Paradigm for Math Education

At present, the colleges and universities to improve education quality and teaching hours to reduce the contradiction of more and more serious, apparently teachers only limits in the classroom teaching process of the limited time is not enough and the improvement of teaching quality finally implement on students' learning quality. Teachers must guide the student to transform the concept, to make the students from the traditional passive to accept knowledge, understanding, knowledge and learning knowledge into the active knowledge acquisition, processing knowledge, apply knowledge, improve their learning ability by using network and improve their comprehensive quality.

In the resource construction should be as the growing demand for the network and raising the level of teaching, constantly improve and update the teaching resources features and content. Resource of development and construction and to make a restructuring, integration of existing teaching resources and modification, which is in accordance with the requirements for digital technology to the existing digital and multimedia teaching resources shall be compiled, adjustment, modification, supplement and perfect and update, in order to adapt to the needs of digital teaching and online teaching, to adapt to the general requirement of era development. All in all, college teaching management involves area wide, is an important part of school work, to school leadership and management personnel to attach great importance to all aspects, and full attention and raise the enthusiasm of teachers and students both sides is the condition and guarantee of teaching quality. In institutions of higher learning, due to its special training objects and training target, need to adhere to the humanistic teaching management, and thus formed the teaching management system.

\section{Conclusion}

In this paper, we conduct research on higher mathematics teaching effective countermeasures for the application-oriented university under background of the informatization. The aim of training applied undergraduate is applied talents, and their scientific research and teaching center should be applied talents. Compared with the ordinary undergraduate course, the applied undergraduate education has obvious practicality while the applied undergraduate research emphasis on practical education value orientation. Practicality is one of the characteristics of teaching and the scientific research of applied undergraduate, allowing it to be the unity of teaching and research, the current must strengthen the unity of the applied undergraduate teaching and research, to make it better service to cultivate applied talents. Need to advocate the practice teaching, strengthening practical education value of scientific research of the applied undergraduate, emphasis on the applied 
undergraduate scientific research and practical application. In the recent future, we will combine more corresponding characteristics of the meth classes with the integration of information technology to look for enhanced teaching mode.

\section{References}

[1] Abdulwahed, Mahmoud, Barbara Jaworski, and Adam Crawford. "Innovative approaches to teaching mathematics in higher education: a review and critique." (2012).

[2] Ottmar, Erin R., et al. "Mathematical Knowledge for Teaching, Standards-Based Mathematics Teaching Practices, and Student Achievement in the Context of the Responsive Classroom Approach." American Educational Research Journal (2015): 0002831215579484.

[3] Abrams, Eleanor, Peter Charles Taylor, and Chorng-Jee Guo. "Contextualizing culturally relevant science and mathematics teaching for indigenous learning." International Journal of Science and Mathematics Education 11.1 (2013): 1-21.

[4] Phillips, Richard J. "An investigation of the microcomputer as a mathematics teaching aid." Computer Assisted Learning: Selected
Proceedings from the CAL 81 Symposium, University of Leeds, 8-10 April 1981. Elsevier, 2014.

[5] Li, Yeping. "Mathematics teacher preparation examined in an international context: learning from the Teacher Education and Development Study in Mathematics (TEDS-M) and beyond." ZDM 44.3 (2012): 367-370.

[6] Provost, Lauren. "Moving Toward Equitable, Accessible, and Relevant Mathematics for All. A Book Review of Rethinking Mathematics: Teaching Social Justice by the Numbers." Democracy and Education 22.1 (2014): 12.

[7] Lau, Wilfred Wing Fat, and Allan Hoi Kau Yuen. "Educational technology training workshops for mathematics teachers: An exploration of perception changes." Australasian Journal of Educational Technology 29.4 (2013).

[8] Chen, Chang-Hua, Chung-Kai Huang, and Chin-Yuan Chang. "Teacher Professional Learning in Applying the Geometer's Sketchpad to Mathematics Instruction." World Conference on Educational Media and Technology. Vol. 2013. No. 1. 2013. 